Jpn. J. Pharm. Health Care Sci.
ノ ー

\author{
地域医療におけるがん疼痛管理に関する \\ 実態調査と問題点の検討 \\ 張替ひとみ ${ }^{* 12}$, 吉田久博 ${ }^{1}$, 片山ひろみ ${ }^{2}$, 住吉美沙江 ${ }^{3}$ \\ 明治薬科大学大学院臨床薬学専攻 ${ }^{1}$ \\ さくら薬局 ${ }^{2}$, かすが薬局 ${ }^{3}$
}

\title{
Research on Pain Control in Cancer Outpatients Taking Opioids Dispensed by Community Pharmacies
}

\author{
Hitomi Harikae ${ }^{* 12}$, Hisahiro Yoshida ${ }^{1}$, Hiromi Katayama ${ }^{2}$ and Misae Sumiyosi ${ }^{3}$ \\ Meiji Pharmaceutical University \\ Graduate School of Clinical Pharmacy ${ }^{1}$ \\ Sakura Pharmacy ${ }^{2}$, Kasuga Pharmacy ${ }^{3}$ \\ $\left[\begin{array}{l}\text { Received February 22, } 2007 \\ \text { Accepted November } 14,2007\end{array}\right]$
}

Although the pain of inpatients suffering from cancer inpatients can be effectively controlled with opioids and other medications by the palliative care team, the pain of many cancer outpatients receiving medication from community pharma cies remains unrelieved. The reasons for inadequate pain control have yet to be clarified but several studies suggest that pa tients' poor understanding of opioids or lack of instruction by pharmacists are behind it.

In order to determine the situation of pain control among cancer outpatients, we conducted a questionnaire survey of pa tients to whom opioids were dispensed by fifteen community pharmacies. The results showed that $23.3 \%$ of the patients achieved complete pain relief through the use of opioids, $22.0 \%$ experienced partial pain relief and $54.7 \%$ received no benefit. We also discovered that $55 \%$ of these patients experienced the adverse effects of constipation, nausea and vomiting and that prescriptions for opioids given to some patients were inadequate. These results suggest that poor pain control is due to inadequate treatment by the primary care physician, especially with regard to opioid prescriptions, and insufficient instruction given to patients by community pharmacists.

Key words — pain control, community basis, pain relief, opioids

\section{緒言}

現在のがん疼痛治療は, WHO 方式がん治療法"1゙根 幹をなしている.このWHO 方式がん疼痛治療法の普 及, 緩和ヶアチームの活躍等により, 病棟では, 個々の 患者に合わせたがん疼痛管理が可能となってきた．しか し，地域医療では，在宅治療中に疼痛コントロール不良 となる症例にしばしば遭遇する．

今回，オピオイド鎮痛薬が処方された外来がん患者の 疼痛管理状況について, 地域薬局 15施設にて実態調査 を行い, 地域医療におけるがん疼痛管理の問題点ついて 検討した。
方法

1. 調査症例抽出期間

平成 17 年 1 月から同年 12 月末までの 1 年間とした .

2. 調査協力薬局

調査目的，調査項目等について事前説明を行い，調査 協力の承諾を得た保険薬局を調査協力薬局とした．

3. 調査症例

調査期間中に, 調查協力薬局にて, オピオイド鎮痛薬 を調剂された外来がん患者から，下記要件を満たす調査 症例を抽出した。

1)薬剂服用歴の記録に, (1)痛みの確認(痛みの質や強 
さ, 軽減等)と(2)副作用の確認(症状や程度, 軽減等)が毎 回明記され，除痛効果判定基準による除痛効果判定が可 能なもの.

2)患者または家族より，データ利用の同意が得られた もの.

\section{4. 調査症例数}

前項の要件を満たす症例で抽出可能な症例数として， 調查協力薬局から回答のあった最少数が 10 例であった ことから, 調査症例数を各調査協力薬局より 10 例ずつ とした .

\section{5. 薬剂服用歴調査}

調査症例の薬剂服用歴の記録から，以下の項目につい て, 調査を実施した。

1)除痛状況

2)オピオイド鎮痛薬の処方状況

(1)処方内容(オピオイド製剤の銘柄, 用法, 用量)

(2)疼痛マネジメント(オピオイドローテーション ,レ スキュードーズ)

3)併用薬の状況

4)副作用発現状況

\section{6. 除痛効果判定基準}

平賀らの報告を参考にして，本調査では，以下の基 準により除痛効果を判定した .

(1)完全除痛 : 痛みの消失, 副作用がないあるいは軽微 (2)一部除痛 : 痛みの軽減，消失はしないあるいは除痛 状況に比し副作用か溞い .

(3)無効 : 痛みの軽減なしあるいは副作用のために中止 した .

除痛状況が变化した場合は, 最終的な状況をもって判 定した。

完全除痛率, 一部除痛率, 無効率は, おのおの症例数 を全症例数で除し求めた。

\section{7. オピオイド換算比}

オピオイド換算比は, オキシコドン: 経口モルヒネ $=$ $2: 3$,フェンタニル貼付剤: 経口モルヒネ $=1: 150$ と した .フェンタニル貼付剤は 1: 100 が適用されること が多いが, 保険適用の点から, 添付文書記載の換算比と した。

\section{1 日投与量, 1 回投与量, 投与回数}

基本オピオイド鎮痛薬の1日投与量は, 症例毎に, 調 査期間中の各製剂の総処方量を総処方日数で除し，当該 製剂の1日投与量とした ・レスキュードーズのオピオイ ド鎮痛薬の1回投与量は, 同樣に, 各製斉の総処方量を
総処方回数で除し，当該製剤の1回投与量とし，投与回 数は, 各製阂の総処方回数を当該処方せんの総受付回数 で除し，当該製剤の1処方の投与回数とした．

\section{9. 用法別除痛構成比率}

1処方 1件ごとの除痛状況をおのおの判定し，用法別 除痛件数を求めた . 用法別除痛構成比率 = 用法別除痛件 数(完全除痛件数 + - 部除痛件数) /用法別全処方件数の 式より求めた .

\section{0. 併用薬の状況}

調査期間中のオピオイド鎮痛薬処方時, 一度でも当該 薬剂が併用処方された症例を併用例とし，一度も当該薬 剂が併用処方されなかった症例を非併用例とした .

\section{結果}

\section{1. 調査基本情報} 1)調査協力薬局

調查協力薬局数は 15 薬局で, 所在地は, 1都 1 道 2 府 6 県にわたっていた。

\section{2)院外処方せん発行医療機関}

院外処方せん発行医療機関数は 20 施設で, 大学病院 7 施設, 一般病院 10 施設, 診療所 2 施設, がん専門病 院 1施設であった .このうち, 診療所以外の 18 施設 $(90.0 \%) に$ 麻酔科外来(ペインクリニック)が設置されて いた .

\section{2. 調査症例基本情報}

抽出された調査症例は, 男性 76 例, 女性 74 例で, 平 均年齢 $64.0 \pm 11.8$ 歳, 最年長 91 歳, 最年少 33 歳であつ た(表 $\mathbf{1}$ ).

受診科は, 外科が $34.6 \%$ で最も多く, 呼吸器内科, 一般内科, 消化器内科がおのおの $10 \%$ 強であった . 麻 酔科受診は 3 例(2\%)であった .

\section{3. 除痛状況}

除痛状況は，完全除痛 35例(23.3\%)，一部除痛 33例 (22.0\%), 無効 82 例(54.7\%)で, 各群の男女比は, ほぼ 1: 1であった(表 1).

処方せん発行医療機関の施設区分別では，症例数が多 かった大学病院と一般病院の除痛状況についてみると， 大学病院では, 完全除痛と一部除痛の合計が 32 例，無 効は 31 例となった .一般病院では, 完全除痛と一部除 痛の合計は 27 例，無効は 47 例であった(図 1).

4. 副作用発現状況

副作用は 83 例(55.3\%)に認められ，発現件数は 111 件 


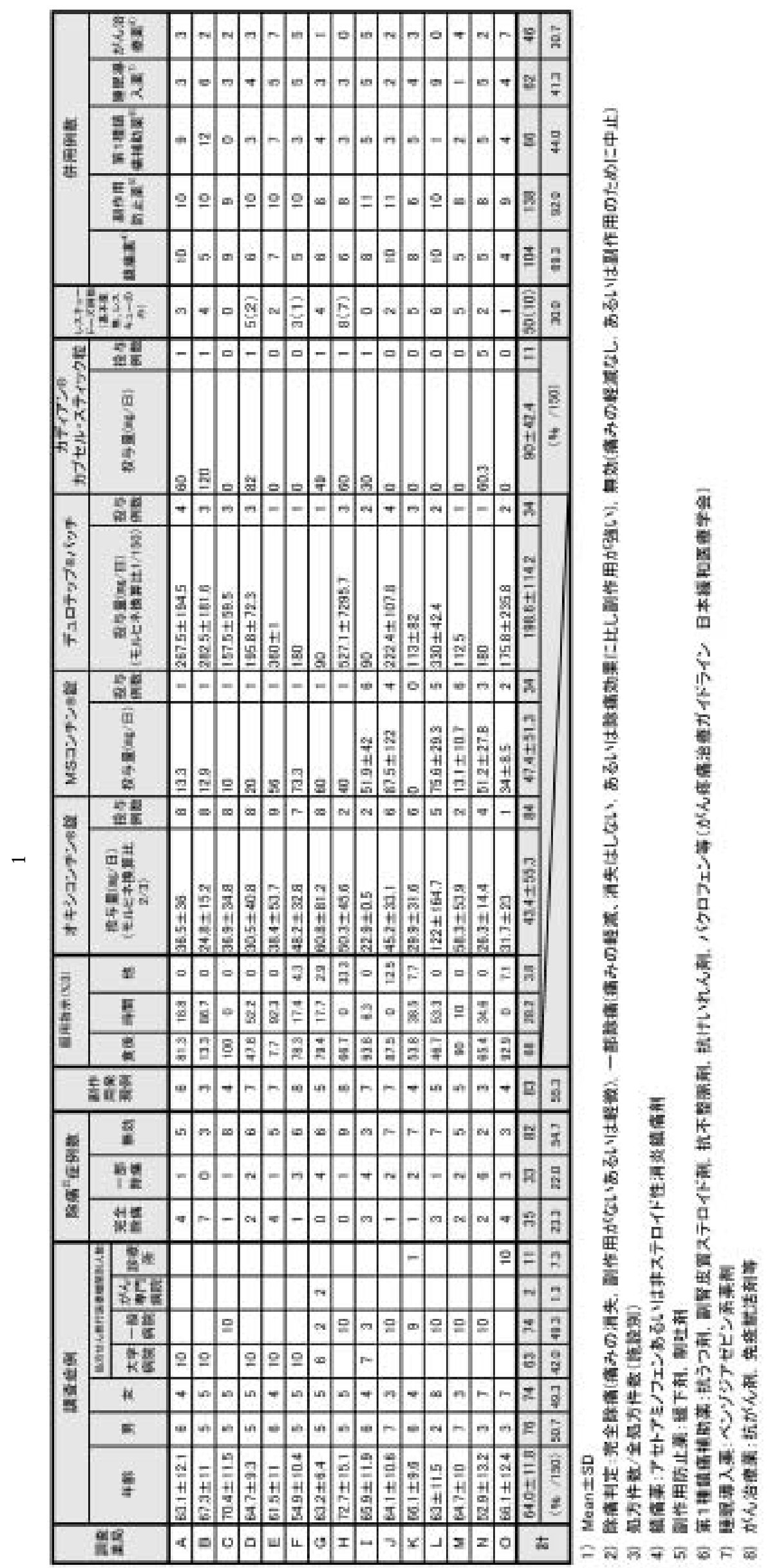


であった．弚の約 7 割が便秘と嘔気・嘔吐であった(図 2).

除痛群ごとの副作用発現率は，完全除痛群 19例/35 例(54.2\%)，一部除痛群 20 例/33例(60.6\%)，無効群 44/ 82 例(53.7\%)であった(図 3) .

製剂別の副作用発現率では，4つの主な副作用発現症 状(便秘, 嘔気・嘔吐, 排尿障害, 傾眠)について，いず

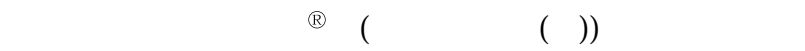
く，次いでデュロテップ®パッチ(ヤンセンファーマ(株)) となった(表 2).

また施設毎では，ばらつきはあるものの，全施設に副 作用発現例があつた(表 1).

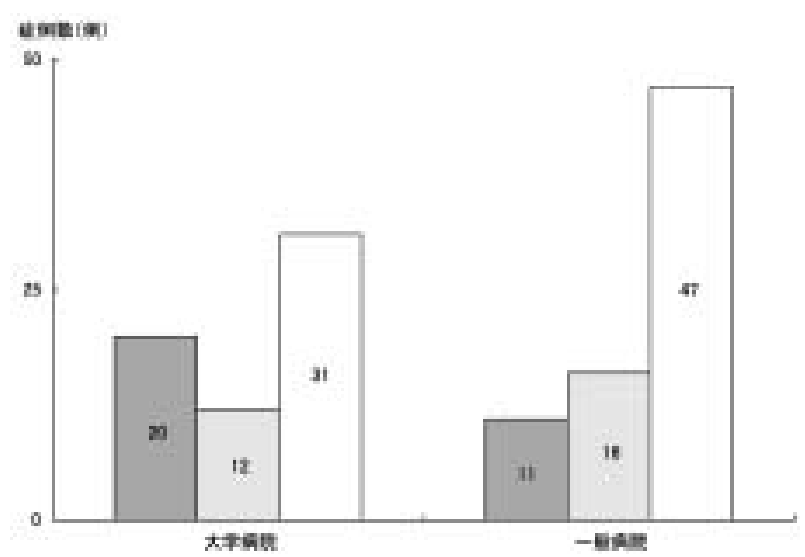

完全除痛 $\square$ 一部除痛 $\square$ 無効

图 1 . 施設区分別の除痛状況
5. オピオイド鎮痛薬の処方状況

1)基本オピオイド製剂の銘柄

基本オピオイド製刘の銘柄は, 塩酸オキシコドン徐放

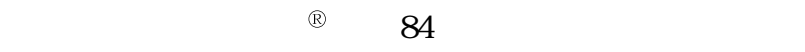
製剂は，MS コンチン踶(塩野義製薬(株))34例，カディ アン ${ }^{\circledR}$ カプセル(大日本住友製薬(株)) 10 例 , カディアン ${ }^{\circledR}$ スティック粒(大日本住友製薬(株))1例で，他の先発品 および後発品の銘柄は処方されていなかった .

フェンタニル経皮吸収剂デュロテップパッチは 34 例で，兴のうち 14例は，モルヒネ製剂からの切替でな く,オピオイド鎮痛薬の開始薬として使用されていた(表 2).

2)基本オピオイド製剂の1日投与量

基本オピオイド製剂の平均 1 日投与量は , オキシコン

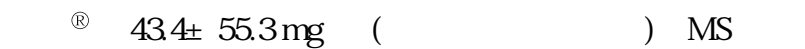
チン ${ }^{\circledR}$ 錠 $47.4 \pm 51.3 \mathrm{mg} /$ 日 , カディアン ${ }^{\circledR}$ カプセル・ス ティック粒 $90 \pm 42.4 \mathrm{mg} /$ 日となった . デュロテップ

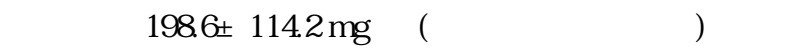

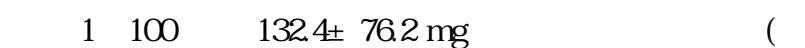
2).

施設ごとでも，オキシコンチン錠およびMS コンチ ン踶に比して，デュロテップ®パッチは高用量の施設 が多かった(表 1).

3)基本オピオイド製剂の使用方法

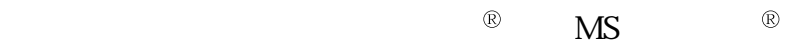
錠の用法指示は，「時間ごと・定時服用」19.8\%，「食後 服用」53.2\%，「炎の他(疼痛時頓用等)」6.9\% の処方率 となった .

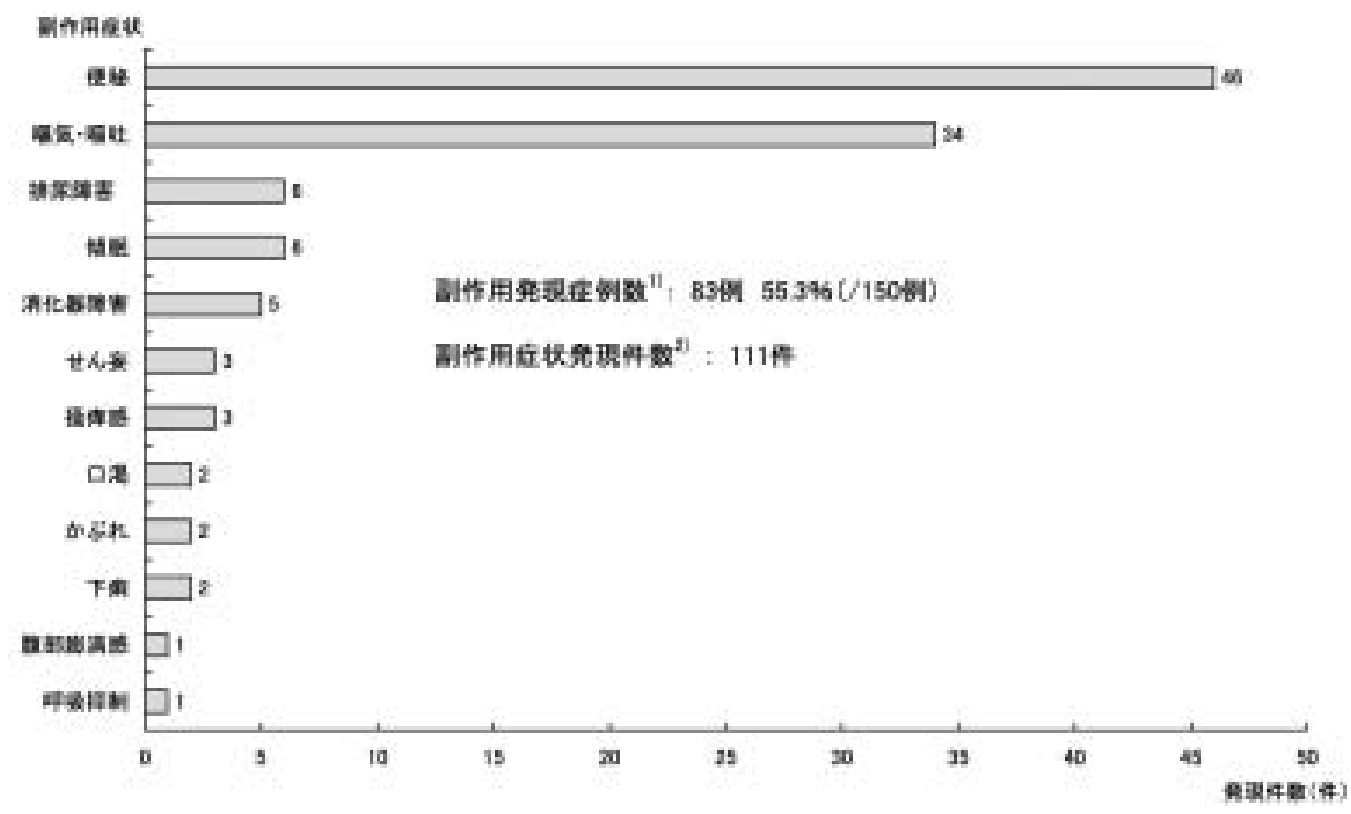

図 2 . 副作用発現の状況

1) 副作用発現例数 : 調査期間中，1つあるいは複数の副作用発現のあつた症例数

2) 副作用発現件数 : 調査期間中, 当該副作用症状を発現した件数 
用法別除痛構成比率は，「時間ごと・定時服用」群 43.1 \%，「食後服用」群 $28.5 \%$,「乥の他」群 $48.0 \%$ となっ た(表 2).

施設間では，すべて「食後服用」指示の施設，90\% 以上「時間ごと・定時服用」指示の施設と，用法に差異 が認められた(表 1).

デュロテップパッチでは,「半面貼付が難しい，失 敗すると貼るのを止める」「3日毎に貼り替えるのを忘れ てしまう」等の使用状況が薬剂服用歴に記載されている 例があつた .

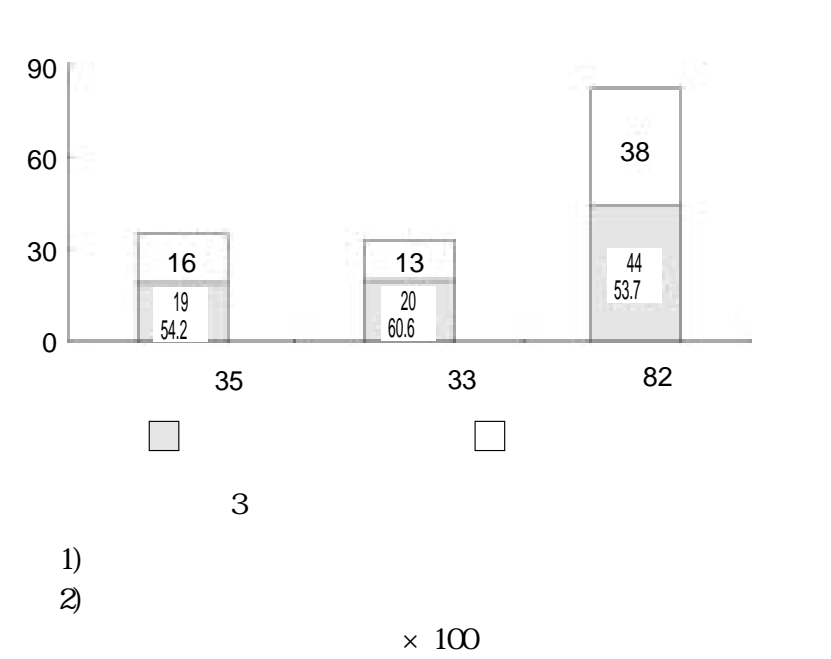

\section{6. 併用薬の状況}

非オピオイド鎮痛薬は, 非ステロイド性消炎鎮痛剂 (以下, NSAIDs と略す)が 103 例(68.7\%)と最も多く，ア セトアミノフェンの併用は1例(0.7\%)のみであった . NSAIDsの内訳は, ロキソニン ${ }^{\circledR} 60 \mathrm{mg}$ 錠(第一三共(株)) 40 例 ,ハイペン ${ }^{\circledR} 200 \mathrm{mg}$ 錠(日本新薬(株)) 13 例および 100 $\mathrm{mg}$ 錠 2 例 , ボルタレン ${ }^{\circledR} 25 \mathrm{mg}$ 錠(ノバルティス ファー マ(株)) 10 例，ボルタレン $\mathrm{SR}^{\circledR} 37.5 \mathrm{mg}$ カプセル(同仁医 薬品化工(株)) 9 例 , モービック ${ }^{\circledR} 10 \mathrm{mg}$ 錠(日本ベーリン ガーインゲルハイム(株))8例 , ナイキサン ${ }^{\circledR} 100 \mathrm{mg}$ 錠(田 辺製薬(株)) 2 例，インテバン ${ }^{\circledR} \mathrm{SP} 25 \mathrm{mg}$ カプセル(大日本

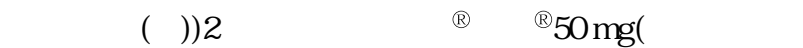
ス ファーマ(株))11例およびサポ ${ }^{\circledR} 25 \mathrm{mg}$ (ノバルティス ファーマ(株))4例，インダシン ${ }^{\circledR}$ 坐剂 $25 \mathrm{mg}$ (サンド(株)) 2 例であつた .

NSAIDsあるいはアセトアミノフェン併用例(以下， NSAIDs併用群と略す)104例とこれらの非併用例(以 下, NSAIDs非併用群と略す)46例の除痛状況をみる と, NSAIDs併用群では, 完全除痛と一部除痛の合計が 40 例，無効 64 例で，一部でも除痛が得られたのは 38.5 \%となった .これに対し，NSAIDs非併用群では，完全 除痛と一部除痛の合計は 28 例，無効は 18例で，一部で も除痛が得られたのは $60.9 \%$ となった(図 4).

副作用防止薬は，緩下剂 135 例(90.0\%)，制吐剂 66 例 (44.0\%)が併用されていた .

兴の他, 第 1 種鎮痛補助薬 ${ }^{33}$ は, 副腎皮質ステロイド

表 2. 基本オピオイド製剂の処方状況

\begin{tabular}{|c|c|c|c|c|c|c|c|c|c|c|c|}
\hline & \multirow{2}{*}{ 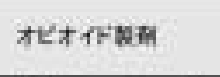 } & \multirow{2}{*}{\multicolumn{2}{|c|}{ 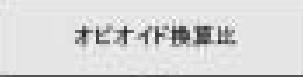 }} & \multirow{2}{*}{ astatents } & \multicolumn{3}{|c|}{ 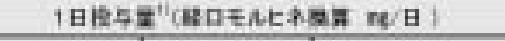 } & \multicolumn{4}{|c|}{ 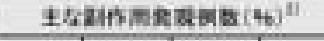 } \\
\hline & & & & & 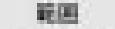 & 中目嘈 & F 1 (b) & $5 k$ & Ex, 1 sut: & in & 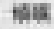 \\
\hline \multirow{4}{*}{$\begin{array}{l}\frac{12}{7} \\
\frac{\mathrm{H}}{\mathrm{H}}\end{array}$} & 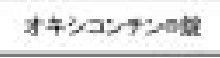 & \multicolumn{2}{|c|}{$2 / 3$} & s4 & $7.5 \sim 205$ & 24.7 & $4.4 \pm 55.3$ & $\begin{array}{c}28 \\
(57.1)\end{array}$ & 26 & $(5.90$ & (3.1) \\
\hline & M8コンチンะに & \multicolumn{2}{|c|}{1} & 34 & $10-270$ & 33 & $47.4 \pm 51.3$ & 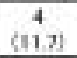 & $(11 \pi)$ & $\begin{array}{c}1 \\
(2 \mathrm{~B})\end{array}$ & $\begin{array}{c}1 \\
(29)\end{array}$ \\
\hline & 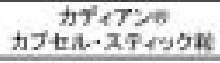 & \multicolumn{2}{|c|}{1} & 11 & $42 \sim 120$ & 42 & $90 \pm 42.4$ & $\stackrel{4}{(36-4 !}$ & $\cos ^{2} 2$ & (1.1) & (2.1) \\
\hline & 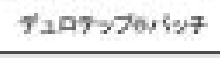 & \multicolumn{2}{|c|}{$1 / 150$} & 34 & $50-540$ & 190 & $156.6 \pm 114.2$ & $\begin{array}{c}14 \\
\langle 412\rangle\end{array}$ & $\begin{array}{c}12 \\
(343) \\
\end{array}$ & $\begin{array}{c}2 \\
(99) \\
\end{array}$ & $\begin{array}{r}2 \\
(59) \\
\end{array}$ \\
\hline \multirow{2}{*}{\multicolumn{2}{|c|}{ 用太萑京 }} & \multirow{2}{*}{ 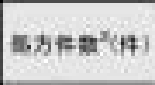 } & \multirow{2}{*}{ 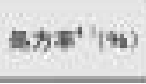 } & \multicolumn{3}{|c|}{ 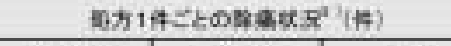 } & m:ABasa & & & & \\
\hline & & & & 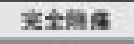 & 一粠紫 & m:ts & 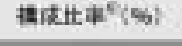 & & & & \\
\hline \multirow{3}{*}{$\begin{array}{l}\text { A } \\
\text { min } \\
\boldsymbol{x}\end{array}$} & 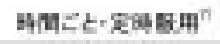 & 72 & 19.8 & 20 & 11 & 41 & 43.1 & & & & \\
\hline & taxisin & 193 & 53.2 & 19 & 36 & 138 & 28.5 & & & & \\
\hline & $t \phi+e^{n}$ & 25 & 5.9 & 6 & 6 & 13 & 48.0 & & & & \\
\hline & 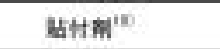 & 73 & 201 & 10 & 11 & 52 & 288 & & & & \\
\hline
\end{tabular}

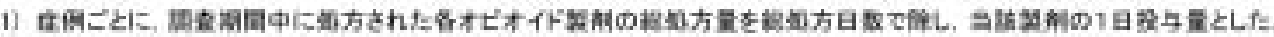

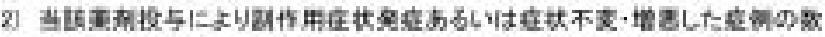

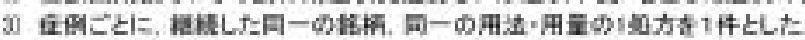

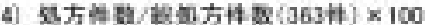

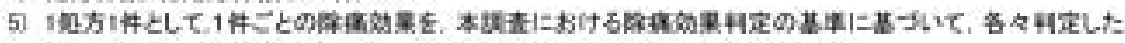

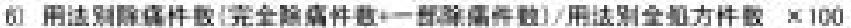

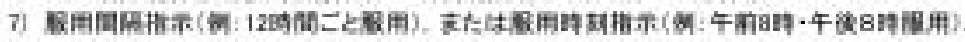

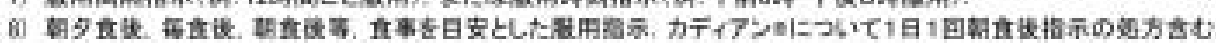

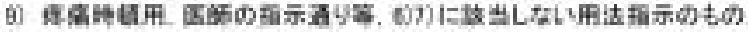

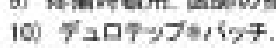




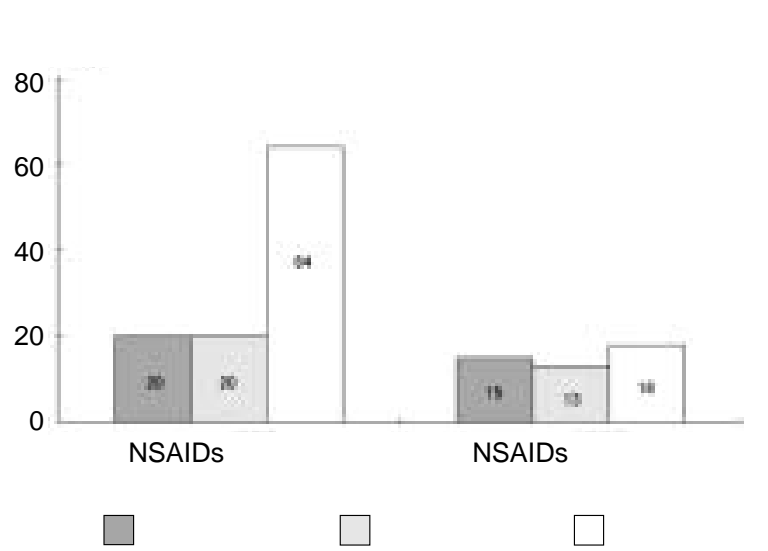

図 4. 非ステロイド性消炎鎮痛剂(NSA IDs)併用と 除痛状況

1) NSAIDs併用群：オピオイド鎮痛薬処方 時 ,一度でもNSAIDsあるいはアセトアミ ノフェンが併用処方された症例 2) NSAIDs非併用群 : オピオイド鎮痛薬処 方時，一度もNSAIDsあるいはアセトアミ ノフェンが併用処方されなかった症例

剂 40 例(26.7\%)，抗うつ斉 18 例(12.0\%)，抗てんかん斉 5 例(3.3\%)，抗不整脈剂3例(2.0\%)が併用されていた . がん治療薬は，抗がん剂およびホルモン剂 46 例(30.7 \%)，睡眠導入薬は 62 例(41.3\%)が併用されていた(表 1).

\section{7. オピオイドローテーションの実施状況}

オピオイドローテーションは 24 例で実施された . 光 のうち 2 種のオピオイド製剂併用にローテーションされ ていた例が3例あった .

除痛状況は，完全除痛 5例(20.8\%)，一部除痛 7 例(29.1 \%)，無効 12 例(50.0\%)であった .

薬斉変更後の投与量が, 前記したオピオイド換算比よ り算出した等鎮痛用量より多い例が 18例あり，逆に少 ない例が 4 例，等鎮痛用量の例は 2 例で，24例の平均 1 日投与量(経口モルヒネ換算，レスキュードーズを含む)

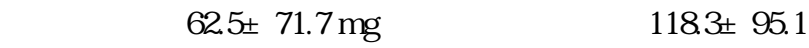
$\mathrm{mg} /$ 日であった .

また，変更後に副作用症状の発現または増悪した例が 11例あった(表 3) .

\section{8. レスキュードーズの処方状況}

レスキュードーズは 50 例に処方され，㚇のうち 3 例 は,オプソ 内服液(大日本住友製薬(株))からアンペック ${ }^{\circledR}$ 坐薬(大日本住友製薬(株)) への変更 2 例, オプソ ${ }^{\circledR}$ 内服液 とアンペック ${ }^{\circledR}$ 坐薬の併用 1 例があった .

除痛状況は, 完全除痛 9 例(18.0\%)，一部除痛 4例(8.0 \%)，無効例 37 例(74.0\%)であった(表 4) .

ぞのうち 10 例は, 基本薬はなく, 速効性オピオイド
製剤の頓用処方のみで(アンペック袡薬 8例，才プソ ${ }^{\circledR}$ 内服液 1 例, 塩酸モルヒネ末 1 例), 全例無効であった . うち 7 例は 1施設の症例であった(表 1).

患者側でも，「我慢できない時にだけ使う」等，頓用 としての使用例もあった .

\section{考察}

今回の調査結果から，地域医療におけるがん疼痛管理 において，オピオイド鎮痛薬の投与を受けているにもか かわらず, 痛みが緩和することなく, 副作用が発現して いる患者が多い実態がうかがえた．

がん疼痛治療において, 痛みの軽減」だけでは, 痛 みに対する患者の不安や恐怖は消えないとされている． WHO 方式がん疼痛治療法によってがん患者の 80 90\% の痛みが和らぐといわれており1)，海外では，WHO 方 式がん疼痛治療法が普及している施設における除痛率は 70\% 以上との報告がある゙ . わが国においても , 経口モ ルヒネ投与の入院末期がん患者における完全除痛率が 49.6\% との調査結果 ${ }^{5}$ がある. 今回の調査結果は, 入院 患者を対象とした報告に比して，極めて低い結果であつ た．弚の要因は, 総じてみて, 医療提供者側の知識不 足, 弚れに起因する不適切な処方内容と不十分な薬局薬 斉師業務(処方監査，疑義照会，服薬指導管理等)，弚れ に加え患者，医療提供者双方のオピオイド鎮痛薬に対す る誤解が主な原因と考えられる。

副作用発現状況は, 便秘と嘔気・嘔吐が主であった . 便秘と嘔気・嘔吐は, オピオイド鎮痛薬投与により，ほ ぼ必発する．したがって，副作用対策は，予防的に対応 することが必要とされている3).しかし，今回は，制吐 剂も $44.0 \%$ の併用にとどまり，副作用対策が十分でな かったと考えられる .

今回の調査では 4つの主な副作用発現症状(便秘, 嘔 気・嘔吐, 排尿障害, 傾眠)について, いずれもオキシ

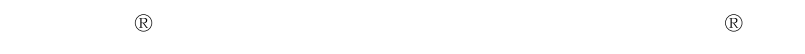
チとなった . 副作用発現については, 便秘はモルヒネお よびオキシコドンではほぼ $100 \%$ にみられ，フェンタニ ルは便秘か軽度であることが多いが, 投与量が増えると 強くなるといわれている。).今回の結果は, 副作用対策 や病状，オピオイド鎮痛薬の投与量が副作用発現状況に 関連したと推測する。

オピオイド鎮痛薬の処方状況では, オキシコンチン ${ }^{\circledR}$ 錠が最も多く処方されていた .オキシコドンは中等度の 痛みから使用でき，腎障害下での鎮静やせん妄等がモル ヒネよりも少ないと考えられている6 .また，等鎮痛用 量で比較すると，オキシコンチン鉎定は徐放性オピオイ ド鎮痛薬の中で最も安価で, 医療経済性の面でも優れて いる.こうした薬阂特性だけでなく，モルヒネという言 


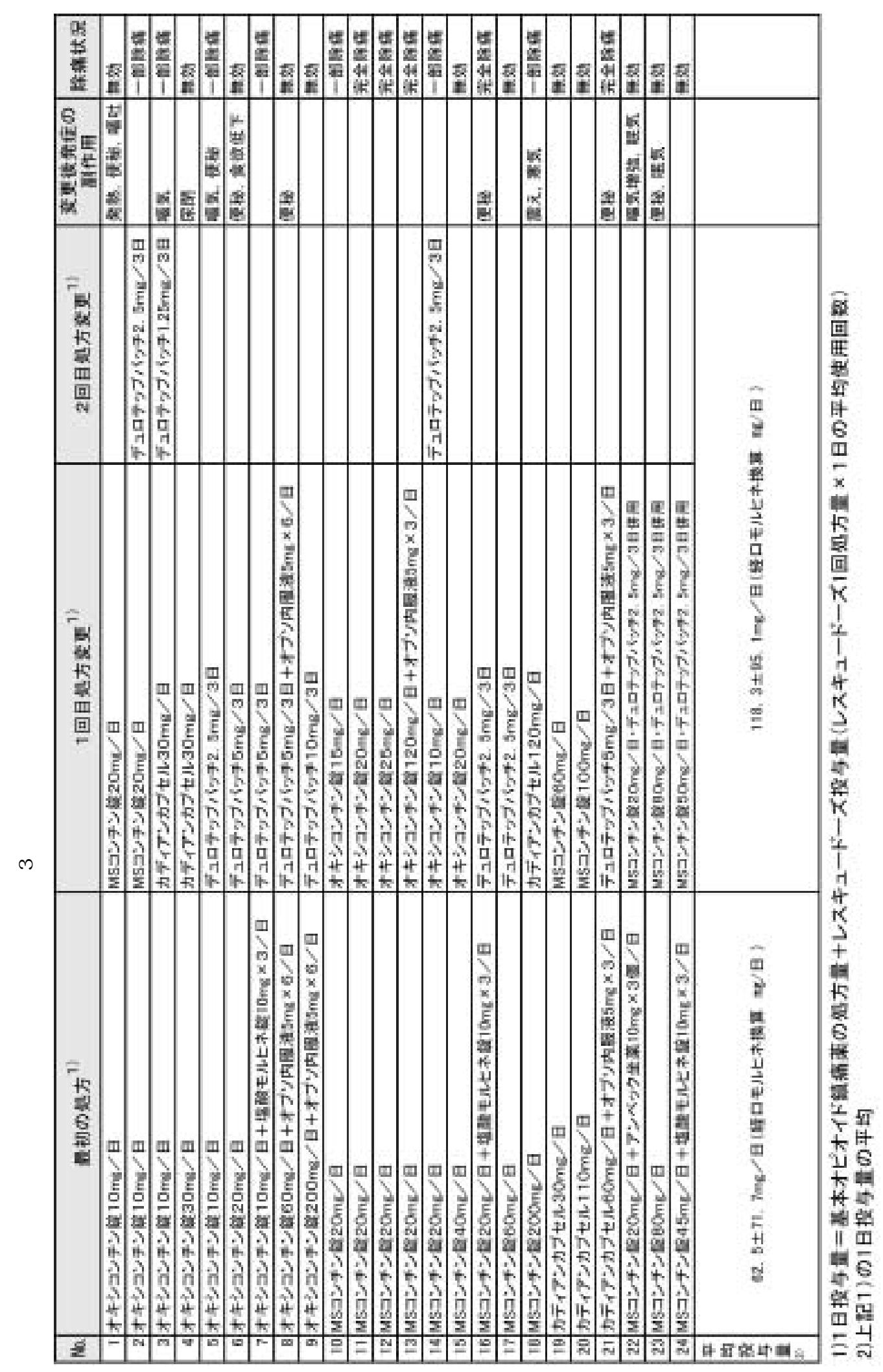


表 4 .レスキュードーズの処方状況

\begin{tabular}{|c|c|c|c|c|c|c|c|c|c|c|}
\hline \multirow{2}{*}{ 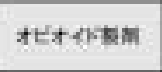 } & \multirow{2}{*}{ ntensin } & \multicolumn{3}{|c|}{ 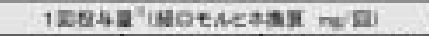 } & \multicolumn{3}{|c|}{$10 \pi 004=\mathrm{a}^{2}$} & \multicolumn{3}{|c|}{ Иล* } \\
\hline & & Ea & pes & 7 tolmantson & ne & peti & $9 \mathrm{n} / \mathrm{mm}=800$ & sesena & - Ind & ns \\
\hline 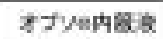 & $23[3)^{\circ}$ & $2.5 \sim 300$ & 10 & $9.2 \pm 73$ & $1 \sim 2 \pi$ & 20 & $36.7 \pm 16.7$ & $T$ & ] & $17(3)^{6}$ \\
\hline 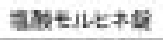 & 3 & $100 \sim 200$ & 100 & $133 \pm 58$ & $10 \sim 28$ & 14 & $173 \pm 25$ & e & a & 3 \\
\hline 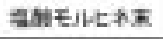 & 5 & $100-15.0$ & 100 & $110 \pm 22$ & $7-2 a$ & 10 & $108 \pm 83$ & 1 & 0 & 4 \\
\hline 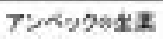 & $1 \mathbf{1}\langle 2\rangle^{6}$ & $100-30$ & 100 & $11.9 \pm 11$ & $30-195$ & 28 & $32.0 \pm 26.7$ & 1 & 1 & $\left(E(3)^{6}\right.$ \\
\hline$s+(9)$ & $\operatorname{soc} 80^{4}$ & & & & & & $s+(\theta)$ & 3 & 4 & $3 \times a i^{\prime \prime}$ \\
\hline $5 \delta \psi^{5}(46)$ & sod & & & & & & 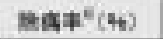 & 180 & 80 & 740 \\
\hline
\end{tabular}

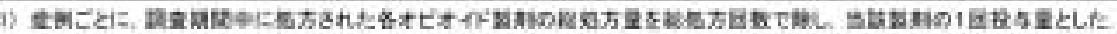

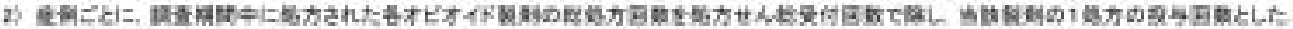

3) x.

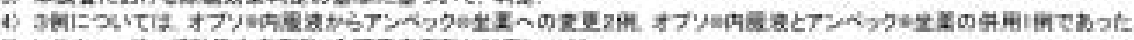

5) LX⿻

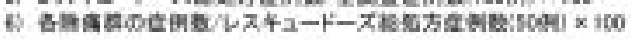

葉に恐怖感や拒絶反応を示す患者にも受け入れられやす いと考えられる．

疼痛コントロールに必要な経口モルヒネの1日量は， がん患者の 85\% で30〜180 mg/日といわれている7 .才 キシコンチン錠も, 調査対象がん疼痛患者の約 $32 \%$ が基本投与量 $80 \mathrm{mg} /$ 日を超える量で投与されていたと いう報告がある ${ }^{8}$.これらの報告と比べ，今回，才キシ コンチン踶，MS コンチン錠両剂ともに少ない投与量 であった .しかし , デュロテップ®゚ッッチの投与量は , 突出していた。

これは, 貼り替え忘れ等の使用状況，また貼付者や貼 付部位の違いにより吸収が変動する゙本阂の特性が影響 していると考えられる．すなわち，本剂の製闵的特徵や 使用方法の複雑さから，老々看護世帯や独居患者等では 適正使用か灘しく，十分な除痛効果が得られないまま増 量され，高用量の経過となったと推測される．また，低 規格製品がなく処方変更量が多くなりがちな状況等も考 えられる。

オキシコンチン錠とMS コンチン鉒において，「時 間ごと・定時服用」群と「食後服用」群の除痛構成比率 を比べると、「時間ごと・定時服用」群で高かった 。こ の結果は，WHO 方式がん疼痛治療法の原則の一つであ る「時刻を決めて規則正しく使用する“ by the clock”」 の重要性を示すものと考えられる . しかし, 経口オピオ イド鎮痛薬全処方中，「時間ごと服用」指示は $19.8 \%$ で， 慣例的な「食後服用」の処方が多く，光の他，徐放性製 剂の頓用処方例もあり，医療提供者側がWHO 方式がん 疼痛治療法をよく認識していない状況が推察される.

併用薬について, 特に問題がない限り, 非オピオイド 鎮痛薬は, オピオイド鎮痛薬と併用が原則であるが ${ }^{3)}$, 今回は，69.3\% の併用にとどまり，併用群は非併用群よ り良好な除痛を得られなかった . NSAIDsの銘柄は，が ん疼痛治療以外でも汎用されているロキソニン錠が最 も多く，WHO 方式がん疼痛治療法の第一段階の基本薬 (イブプロフェン，インドメタシン等)や代替薬(ナプロキ
セン , ジクロフェナク等) ,また $\operatorname{cox}-2$ 選択的阻害薬の 併用も少なかった .NSAIDsは, 薬阂個々でさまざまな 特徵があり，効果や副作用等の特徵を理解し使い分ける 必要がある ${ }^{10}$ が, 今回は, 弚うした使い分けの樣子はう かがえなかった .こうした状況が，併用群と非併用群の 除痛状況に関連していると推測される . ステロイド斉以 外の鎮痛補助薬の併用率は $17.3 \%$ と低值で, 無効例で 長期間併用されている例もあった . これらの状況から， 痛みの質に応じた併用薬の選択はなされてはいなかった と推測される .

オピオイドローテーションを実施した 24 症例におけ る除痛効果は完全除痛率 $20.8 \%$ で，ローテーション後 に増量しても，半数の症例では痛みの軽減か認められ ず，ローテーションの多くが不適切なものであった可能 性も否定できない .

レスキュードーズの処方率も $30.0 \%$ と低く，処方例 でも十分な除痛効果認められなかった .この一因とし て, 1処方の投与回数が平均 $32.0 \pm 26.7$ 回で, 1 日 2 回 程度しか処方されておらず，保険適用の観点から十分に 使用できない状況となっていることが考えられる . また，一般的な頓用としての使用例もあり，レスキュー ドーズか効果的に運用されていなかった症例が多かった といえる．

施設間では，除痛状況について，大学病院に比心゙,一 般病院は劣っていた .用法指示では,す心゙て「食後服用」 指示の施設もあるが，逆に $90 \%$ 以上「時間ごと・定時 服用」指示の施設もあり，指示の状況に差異があった . また ,レスキュードーズについても，基本薬なしの速効 性オピオイド製剂の頓用処方 10 例のうち 7 例は 1 施設 からの症例であった .このようにオピオイド鎮痛薬の処 方状況にも差異があった . 今回の調査で, これについて 明確にすることはできないが，こうした処方状況の差異 が除痛成績に影響している可能性がある。

これらの状況の根本的な問題点として, (1)WHO 方式 がん疼痛治療法や各オピオイド製剂の特性に関する医療 
提供者側の知識不足，(2)薬局薬剂師業務の不十分(処方 監査，疑義照会，服薬指導管理等)，(3)患者，医療提供 者双方のオピオイド鎮痛薬に対する誤解，(4)患者および 介護者と医療・介護スタッフの連携不足，(5)地域におけ る緩和ケアの専門施設・サービス体制の不足等が考えら れる。

地域医療では，医療と介護が混在し，おのおのの領域

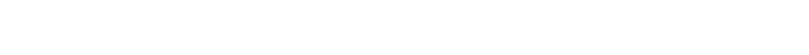
では，双方の連携や施設面の充実も図られているが，が ん患者はこうしたサービスから取り残されている感があ る.こうした状況下，双方の領域を職能とする薬局薬剤 師の役割は重要と考える.高齢化，核家族化が進み，老々 看・介護, 独居のがん患者も多く, トータルペインとし ての痛みの管理も重要となる.生活の場にある地域医療 に支える者として，医療と介護双方の調整を図りなが ら, 薬斉師職能を発揮することが薬局薬剂師に求められ ていると考える．

今後の薬局薬斉師の役割として，医療や介護のスタッ フと連携し疼痛管理に努め，弚れを踏まえ，個々の患者 に適切な院外処方せん発行に関与する．また，個々の患 者や介護者に対して十分な服薬指導・管理を行い，患者 側の適正なオピオイド鎮痛薬使用を支援するという2つ が最重要であると考える.

謝辞 今回の調査にこ協力いただきました薬局薬剤師の皆 様に，心より感謝いたします．

\section{引用文献}

1) 武田文和訳“, がんの痛みからの解放”, 第 2 版，世界 保健機関編，金原出版，2003, pp.3, 40-41.

2) 平賀一陽, 武田文和, 水口公信, 日本におけるがん 患者の疼痛の出現率・鎮痛法の現状と除痛率の改善 度, 厚生省がん研究助成金終末期がん患者の苦痛緩 和に関する研究平成 2 年度報告書, 1991 年 4 月， pp.15-16.

3) 日本緩和医療学会がん疼痛治療ガイドライン作成委 員会“, Evidence Based Medicineに則つたがん疼痛治 療ガイドライン”，真興交易医書出版部，2000, pp. 80-91.

4) V. Ventafridda, M. Tamburin, A. Caraceni, F.De Conno, F. Naldi, A validation study of the WHO method for cancer pain relief, Cancer, 59, 850-856 (1987).

5) 平賀一陽，本邦における癌性疼痛管理の現況と今後 の展望 ，ペインクリニック， 20, 79-484 (1999).

6) 的場元弘“, がん疼痛治療のレシピ”, 春秋社 , 2007, pp. 94-95.

7) 国立がんセンター中央病院薬斉部“, モルヒネによる がん疼痛緩和”,改訂版，エルゼビア・ジャパン， 2004, p. 217.

8) 武田文和, 下山直人, がん疼痛緩和対策のアドバイ ス，がん患者と対症療法，17, 63-64 (2006).

9）沼田千賀子, 寺岡麗子, 松田芳久, 三谷祥子, 宮長 祐子，八木敬子，平井みどり，使用済みフェンタニ ルパッチ内のフェンタニル残存量の測定および残存 率に及ぼす要因 - 個人差および貼付部位 - ，医療薬 学, 31, 599-605 (2005).

10）加賀谷肇，的場元弘，田中昌代“，がん疼痛緩和ケア Q\&A”，じほう，2006, p. 59. 